\title{
Potential Location for Extensification of Organic Rice Field in Tasikmalaya District
}

\author{
${ }^{1}$ IVAN CHOFYAN, ${ }^{2}$ ROHMAWATI MARDIAH \\ 1,2, Universitas Islam Bandung, Indonesia. \\ Correspondence author: chofyanivan@gmail.com
}

\begin{abstract}
Tasikmalaya District is one of the districts that have succeeded in producing export quality organic rice. Organic rice export demand reaches 320 tons per year, while the amount of organic rice production produced is only 20-30 tons, which means it has not been able to fulfill market demand. This potential should be utilized by increasing the amount of organic rice production, one of which is through extensification. The purpose of this study is to determine potential locations for the extensification of organic rice fields as an effort to increase organic rice production to meet market share. This study uses quantitative method and conducts analysis on land capability, land suitability, and irrigation water. The result of the study states that the cultivation area is $14,860.53$ hectares, where 10,155.01 hectares of it is suitable for developing rice fields with adequate water availability that can fulfill the water needs of the rice fields.
\end{abstract}

Keywords: Location, Extensification, Organic

\section{Introduction}

Indonesia, up until now, still applies the conventional agricultural system. The conventional farming system causes negative impacts for the environment and consumers; thus, to deal with it, the farming system needs to change from conventional to organic. The difference between organic and conventional agriculture lies in the sustainability of ecosystems and agricultural products (Imani, Anne, Tuti, \& Gema, 2018). So far, farmers tend to use inorganic fertilizers constantly. The relatively high and continuous use of inorganic fertilizers can cause negative impacts on the soil environment, thereby, reducing soil productivity. These conditions lead to the thought of re-using organic materials as a source of organic fertilizer.

The use of organic fertilizer is beneficial since it is able to maintain the soil balance and increase soil productivity and also reduce the negative environmental impact on the soil (Supartha, Wijana, \& Menaka, 2012). Organic farming attempts to minimize the negative impacts on the surrounding nature with the main characteristic of using local varieties, fertilizers, and organic pesticides to preserve the environment (Firmanto, 2011). The process of organic farming cultivation relies on materials from nature without using synthetic chemicals (Fagi \& Las, 2007).

Tasikmalaya District is one of the districts that have successfully developed an export quality organic rice field that has passed certification from the Organic Certification Institute (LSO) and the National Accreditation Committee. Based on data obtained from Kabupaten Tasikmalaya dalam Angka (Tasikmalaya District in figure) 2018, the total rice field area in 2017 was 51,297 Ha, while the area of organic rice fields reached $7,102 \mathrm{Ha}$ or around $13.84 \%$ of the total rice field area.

The total organic rice exports from 2009 to 2017, as reported from jabar. antaranews. com and Indonesian Organic Alliance (AOI), reached 771,981 tons with destinations to various countries such as Malaysia, Singapore, Taiwan, Japan, the United States, Canada, Italy, Belgium, and Germany (AOI, 2018). $80 \%$ of organic rice market share is overseas and $20 \%$ is local. 
Organic rice export demand reaches 320 tons per year, but the amount of organic rice production produced by Tasikmalaya District during the harvest season ranges only from 20-30 tons. It means it has not been able to fulfill the market demand. Thus, an increase in organic rice production is needed to meet market share through restoring land quality and preserving the ecosystem so that it would also impact on increasing farmer's income.

Organic rice fields in Tasikmalaya District exist in four sub-districts, namely Cisayong, Manonjaya, Salawu, and Sukahening which are developed by the Simpatik Gapoktan (farmers' group association of Simpatik). There are 35 or $89.74 \%$ of sub-districts that have not yet developed organic agriculture, even though organic farming is more profitable compared to conventional one in terms of economy, quality, health, ecology, and sustainability. The big opportunity offered by organic rice farming development leads the Tasikmalaya District government to promote a new organic rice field-building program out of unproductive land owned by the residents. Later on, the residents will get their lands back. Building new organic rice fields is an implementation of one of the priority programs in the Gerakan Bangun Desa or Gerbang Desa (a movement to build the village) aim at improving the welfare of farmers, farm laborers, fishermen, and village officials.

Rice field development plans are also listed in the 2016-2021 Tasikmalaya District RPJMD (Long-Term Regional Development Program) in agriculture. In accordance with the second mission of Tasikmalaya District that is to create a resilient economy in the field of agribusiness and tourism, the target of organic rice field development is $8,585 \mathrm{Ha}$ and has only been realized for 3,200 Ha in 2016 or needs $5,385 \mathrm{Ha}$ to achieve the specified targets. The building of new organic rice fields is one of the steps taken by the government to realize the 2016-2021 RPJMD and increase the production of organic rice by extensification.

Studying the determination of potential locations for the development of organic rice fields is necessary to support Tasikmalaya District government program in increasing the organic rice production by extensification. Subdistricts that have not yet developed organic rice fields include Karangnunggal and Cipatujah. Karangnunggal and Cipatujah Subdistrict are located in the southern part of Tasikmalaya District and are directly bordered by the Indian Ocean so that both districts have coastal areas. The area of Karangnunggal Subdistrict is $13,633 \mathrm{Km} 2$ and the area of Cipatujah Subdistrict is 24,667 $\mathrm{Km} 2$. Karangnunggal Subdistrict consists of 14 villages with 12 villages as rural areas and 2 villages as urban areas, while Cipatujah Subdistrict consists of 15 villages which are all rural areas.

The purpose of this study is to determine potential locations for the development of new organic rice fields. The development of organic rice fields includes the development on new land and the conversion from conventional to organic planting rice systems. The planned villages as the location for developing new rice fields are 13 villages in accordance with the Tasikmalaya District RTRW in 2011-2031, with the details of 4 villages in Karangnunggal Subdistrict and 9 villages in Cipatujah Subdistrict. The villages in Karangnunggal Subdistrict are Cikapinis, Sarimukti, Kujang, and Cidadap Villages; while the villages in Cipatujah Subdistrict are Cikawunggading, Sindangkerta, Kertasari, Cipatujah, Padawaras, Darawati, Bantarkalong, Tobongjaya, and Neglasari.

Organic farming is an agricultural production system based on biological recycling. Plant and livestock waste facilities can do nutrient recycling, as well as other wastes that can improve fertility status and soil structure. The organic farming system is a law of return; a system that seeks to return all types of organic material into the soil in the form of residues and plants and livestock waste which subsequently aims to feed the plants (Saragih, 2008). The philosophy underlying organic farming is to develop the principle of feeding the soil that feeds the plants instead of feeding the plants directly (Sutanto, 2002).

Organic farming prioritizes the stability of the ecosystem and the balance of elements in the soil. It is also compatible with the ecosystem and natural plants and can reduce pollution to a minimum since it emphasizes the use of compost to maintain soil carbon elements. The application of organic farming systems is one way to increase crop production while keeping/returning the quality of agricultural land. Organic farming systems support the environmentally friendly cultivation systems, change the physical and chemical properties of the soil for the better, and encourage the development of microorganisms that guarantee soil fertility 
(Hamka, Sitti, Rita, \& Ary. 2018).

Khorniawati's research (2014) concluded that some people began to realize and care about their health and environment so that they started consuming organic agricultural products. Organic agricultural products are good for health and the environment because they contain no chemicals since organic farmers do not use chemical fertilizers during the process of production. In addition to health and the environment, farmers add that organic farming is an agricultural system that considers all aspects of life, human relations with other humans, human relation with nature, and human relation with God (Wiratmadja, Noneng, \& Amelia, 2017). This condition shows that the more positive the farmer's attitude towards organic farming, the greater the farmer's intention to apply organic farming.

According to IFOAM (International Federation of Organic Agriculture Movements) (2005), organic agriculture is a holistic farming system that supports and accelerates biodiversity, biological cycles, and soil biological activities. The objectives of applying organic farming systems according to IFOAM include:(1) to encourage and improve the recycling process in the farming system by activating the life of microorganisms, flora and fauna, soil, plants, and animals; (2) to guarantee a better life according to human rights for agricultural producers (especially farmers) so that they can meet basic needs and get income and job satisfaction, including a safe and healthy work environment; and (3) to maintain and improve soil fertility in a sustainable manner.

The method of organic farming in each country could vary. Nevertheless, it shares the same goal as an effort to protect soil, biodiversity, and to give animals and poultry the opportunities to graze in the open (Sutanto, 2002). Organic farming, on the other hand, also seeks to improve health and productivity among flora, fauna, and humans. The use of inputs from outside of agriculture that damage the natural resources cannot be categorized as organic farming. On the contrary, agricultural systems that do not use external inputs but follow the rules of organic farming are included in the organic farming group, even though the agro-ecosystem does not receive organic certification.

Kementerian Pertanian (Ministry of Agriculture) (2007) in the Road Map for Development of Organic Agriculture 2008-
2015 stated that organic farming in practice was carried out in the way of, among others: (1) avoid using GMO (Genetically Modified Organism) seeds; (2) avoid using synthetic chemical pesticides (controlling weeds, pests and diseases carried out by mechanical, biological, and crop rotation); (3) avoid using growth regulators and synthetic chemical fertilizers (soil fertility and productivity are increased and maintained by adding natural manure and mineral rocks and planting legumes and crop rotations); and (4) avoid using growth hormones and synthetic food additives in animal feed.

Paddy rice is one of the food-producing commodities, namely rice. The general structure of rice seeds consists of 3 parts, namely seed coat, endosperm, and embryo. The rice husk is rice seed coat, while the ricegrain is grain of seed and embryo (Muchtadi, 2010). Organic rice comes from paddy rice cultivated organically or without the use of chemical fertilizers and pesticides and applies the organic food system along the way up to the hands of consumers. Organic rice is safe for consumption because it is free from chemical residues (Sriyanto, 2010). The community considers organic rice to be healthier, safer, and has more nutrition than conventionally cultivated rice because it is free of pesticides.

In terms of quality, rice produced from organic farming systems is healthier than conventional one because it does not use chemicals and synthetic substances that can pollute agricultural products. It is also more durable and can maintain the stability of national food security since it does not cause land degradation so that it has a sustainable nature. The adoption rate of organic rice cultivation has a positive effect on the sustainability of organic rice cultivation. The higher the level of adoption of organic rice cultivation, then the higher the level of sustainability of organic rice cultivation and vice versa. The adoption of organic rice cultivation will continue if it can increase productivity and income, or give economic and social benefits to the farmers (Permatasari, Sapja, \&Widyatmani, 2018).

In terms of price, rice produced from the organic farming system has a much higher price: organic unhusked dry rice has a selling price of around Rp. 12,000/kg while the inorganic has only a selling price of around Rp. 4,000/kg; the price of organic rice can reach $\mathrm{Rp} .25,000 / \mathrm{kg}$, while the inorganic 
only reaches Rp. $15,000 \mathrm{~kg}$, and the market reach of organic agricultural products is wider than conventional ones. Higher prices and the wider market can help organic rice farmers to improve their welfare.

Research conducted in several countries that comparing organic to conventional agriculture mostly state that the benefits derived from organic agriculture outweigh the benefits gained from conventional one. It is because organic farming does not spend much of the costs for the purchase of fertilizers, chemical pesticides, and other agricultural inputs; besides that, organic products sell at a higher price (Greer, 2008). Amalia conducted a study in 2013 entitled "Perbedaan Sistem Tata Niaga Beras Organik dan Beras Anorganik" (The Difference between Organic and Inorganic Rice Trading System) with the conclusion that the organic rice trading channel is shorter than the inorganic rice. The organic rice trading channel is shorter because trade agencies being involved are smaller, namely producer farmers selling unhusked dry rice to group institutions that act as collectors and processors.

Meanwhile, research conducted by Lutfi in 2017 entitled "Analisis Pendapatan Usahatani Padi Organik dan Non-Organik di Kabupaten Tasikmalaya Provinsi Jawa Barat" (Analysis of Organic and Non-Organic Rice Farming Revenues) concluded that organic rice farming was profitable in terms of total farm income and the value of $\mathrm{R} / \mathrm{C}$ ratio. The profit showed in the results of different t-test stating there was a significant difference between organic and non-organic rice farming in cash costs, cash receipts, total income, and $\mathrm{R} / \mathrm{C}$ ratio of cash receipts.

Fundamentally, the conditions for growing organic rice are the same as regular rice. Rice plants can grow well in hot areas containing a lot of water vapor with rainfall averaging $200 \mathrm{~mm} / \mathrm{month}$ or more with distribution for 4 months. The desired rainfall is around $1500-2000 \mathrm{~mm}$ /year with altitudes ranging from 0-1500 $\mathrm{m}$ above sea level. Rice plant generally need a minimum temperature of $11^{\circ}-25^{\circ} \mathrm{C}$ for germination, $22-23^{\circ} \mathrm{C}$ for flowering, $20^{\circ}-25^{\circ} \mathrm{C}$ for seed formation, and a hotter temperature for all growth because it is suitable for rice plants, especially in the tropics. Air temperature and light intensity in the surrounding environment of paddy rice has a positive correlation to the process of photosynthesis, i.e. the making of food for plant growth and fruit or seed production
(Andoko, 2005).

Applying the technology in organic agriculture needs preparation, and one of the elements required is land resources (Gribaldi, 2009). It is important to find out about the characteristics of land resources first so that they can be used optimally. Evaluation of land resources can determine the suitability of land (Rusiyah, Djarot, \& Tukidal, 2012). Land suitability classification provide information on land limiting factors for the development of organic lowland rice farming.

\section{Research Methodology}

This research applies quantitative method and performs analysis of land capability, land suitability, and irrigation water availability. The location designated as an organic rice field extensification must have 3 requirements, namely: (1) it should be a cultivation area, not a protected area. An analysis of land capability by applying Keppres No. 32 of 1990 can help determine a cultivation area; (2) it has minimal land suitability at the sub-class marginally suitable $\left(\mathrm{S}_{3}\right)$. The land suitability analysis is done using guidelines issued by the Bogor Puslittanak (Center for Soil and Agroclimate Research); and (3) it has water sources for irrigation. A calculation needs to perform to find out the capacity of irrigation water availability.

Land capability analysis serves to determine protected areas and cultivation areas. The protected area is an area designated with the main function to protect environmental sustainability which includes natural and human-made resources. According to Keppres No. 32 of 1990 and PP (government regulation) No. 13 of 2017 concerning the National Spatial Planning (RTRWN), protected areas have their respective types and distribution. Protected areas consist of areas that protect subordinate areas, locally protected areas, areas of nature reserves and cultural reserves, and areas prone to natural disasters. Measuring the objects that have been determined, superimpose, and scoring on certain parameters listed in Keppres No. 32 of 1990 is a way to determine protected areas. This analysis produces a map of protected areas, so that areas not included in protected areas can be called cultivation areas. The location of potential extensification of organic agriculture must be in cultivation areas.

The protected forest areas determined based on the results of the scoring of each 
land unit (LU) with the following conditions: (a) total score > 175; and/or (b) protected forest if its slope $>40 \%$; and/or (c) protected forest if it has an altitude of $>2000$ meters above sea level. Data needed to analyze the determination of protected forest areas are soil type, slope, land altitude above sea level, and rainfall intensity. Meanwhile, other protected areas are determined using the criteria written in the articles of Keppres no. 32 of 1990, starting from article 9 to article 33.

Land suitability analysis carries out after land capability analysis, and it only applies to areas designated as cultivation areas. The purpose of land suitability analysis is to find out the land suitable for developing paddy rice. Land suitability analysis carries out using superimpose techniques through guidelines issued by the Bogor Puslittanak. This study uses eleven factors to evaluate land suitability. Data needed to conduct land suitability analysis are soil type, slope, altitude, and climate. There are 3 types of soil found in the study area, namely Alluvial, Andosol, and Podsolik. Table 1 shows the soil characteristics used as determinants of land suitability.

The climate classification used in this analysis is the Oldeman climate classification. Oldeman determines climate classification by considering wet and dry months. Wet months are months with rainfall above 200 $\mathrm{mm}$ per month, while dry months are months with rainfall below $100 \mathrm{~mm}$ per month. Karangnunggal and Cipatujah Subdistricts have 5-6 wet months and 2 - 3 dry months so that they include in the C2 climate type. The altitude in the study area has a uniform value of $<500 \mathrm{~m}$ above the sea level (asl) which makes it included in the lowland category. The slope found in the study area varies from $0 \%$ to above $40 \%$ (see Table 2 ).

There are 2 land suitability classifications, i.e. actual land suitability and potential land suitability. Actual land suitability shows the suitability of land designation determined in the present condition before any improvement. Potential land suitability indicates the states of land suitability after the improvement. The improvements must be in line with the level of prior land suitability assessment. This potential land suitability is the expected condition after being given input according to the level of management that will be applied. The examination of land characteristics incorporated in each land quality is essential in determining the type of improvement effort. Land characteristics can be distinguished by the nature of the land that can be improved and that which cannot be improved.

The third analysis is the analysis of irrigation water availability. Determination of the rice field area does not only consider the capability and suitability of the land, but also requires an analysis of the availability of irrigation water to support the sustainability of rice field development activities. Limited availability of irrigation water will affect the intensity and farmers' cropping patterns (Darwanto, 1999). The potential availability of irrigation water comes from rivers in the

Table 1

Soil Characteristics

\begin{tabular}{|l|l|l|l|l|}
\hline \multirow{2}{*}{ No } & \multirow{2}{*}{ Factor } & \multicolumn{3}{c|}{ Soil Type } \\
\cline { 3 - 5 } & & \multicolumn{1}{c|}{ Alluvial } & \multicolumn{1}{c|}{ Andosol } & \multicolumn{1}{c|}{ Podsolik } \\
\hline 1 & Effective Depth & $<50 \mathrm{~cm}$ & $100-225 \mathrm{~cm}$ & $90-180 \mathrm{~cm}$ \\
\hline 2 & Class of Grain Size & Soft clay & Soft clay & Coarse-loamy \\
\hline 3 & Permeability & Slow & Fast & Slow \\
\hline 4 & Fertility & High & High & Low \\
\hline 5 & pH & $5,0-5,9$ & $5,0-7,0$ & $4,5-5,0$ \\
\hline 6 & Class of Drainage & Rather fast & Fast & Rather hinder \\
\hline 7 & Erodibility & Medium & Very sensitive & Rather high \\
\hline
\end{tabular}

Table 2

The Slope

\begin{tabular}{|c|c|c|}
\hline No & Slope & Description \\
\hline 1 & $0-8 \%$ & Flat \\
\hline 2 & $8-15 \%$ & Sloping \\
\hline 3 & $15-25 \%$ & Rather steep \\
\hline 4 & $25-40 \%$ & Steep \\
\hline 5 & $>40 \%$ & Very steep \\
\hline
\end{tabular}


study area and existing irrigation networks. Before calculating the potential availability of irrigation water, it is necessary to determine the irrigation water requirements for rice fields. Having knowledge of the potential availability of irrigation water and water needs can identify areas potential for building new rice fields.

Irrigation water requirements consist of crop water requirements (CWR), farm water requirements (FWR), and irrigation water requirements (IWR). CWR is the amount of water used for evaporation from the surface of water or plants and is used by plants to build body tissues. Plant factors influence the value of consumptive water demand according to their growth period and water evaporation from the land surface, especially agricultural land. FWR is the water requirement for a unit of planting area, which is the amount of crop water requirements plus the amount of water loss on agricultural land in the form of percolation influenced by effective rainfall on agricultural land. IWR is the amount of water needed for all land that is determined by the farm water requirements and the efficiency of irrigation canals (Partowijoto, 1996). The formula of irrigation water requirements is as follows:

$I W R=F W R / E f$

Description :

IWR = Irrigation water requirement ( $\mathrm{mm} /$ day)

FWR = Farm water requirement $(\mathrm{mm} /$ day $)$

$\mathrm{Ef} \quad=$ Irrigation canal's efficiency (\%)

According to Partowijoto (1996), the farm water requirements for rice fields is $9.8 \mathrm{~mm} /$ day or $2.0 \mathrm{It} / \mathrm{sec} / \mathrm{ha}$. With an irrigation canal's efficiency value of $93 \%$, the irrigation water requirements are $10.54 \mathrm{~mm} /$ day or $2.15 \mathrm{It} /$ $\mathrm{sec} / \mathrm{ha}$. Building an Irrigation canal on the land that has been declared suitable for developing rice fields and has already had irrigation water is important to avoid the land conversion into other uses; there are laws that prohibit the conversion of irrigated rice fields. Based on the dynamic model created by Chofyan in 2016, the conversion of rice fields in Bandung District will cause a decrease in rice production in the future. Irrigated rice fields will become the physical foundation for the development of organic rice fields in Karangnunggal and Cipatujah Subdistricts.

\section{Results And Discussion}

The first step taken in this study is the analysis of land capability. Land capability analysis serves to divide the study area into protected areas and cultivation areas.
The protected areas consist of protected forest areas and other protected areas. The protected forest area is a forest area with unique characteristics that can protect the surrounding area and subordinates and act as regulators of water management, flood prevention, and erosion as well as maintaining soil fertility.

Based on the analysis, the protected areas in the study area consist of protected forests, water catchment areas, coastal borders, river borders, areas around water springs, nature reserves and cultural reserves, and areas prone to natural disasters. Criteria for water catchment areas are high rainfall, soil structure that is easy to absorb water and geomorphological forms that are capable of absorbing large-scale rainfall. The coastal border is a land along the coast which is proportional to the shape and physical condition of the beach, at least 100 meters from the highest tide point towards the land. There are 2 criteria for river border: first, it is at least 100 meters on either side of a large river and 50 meters on either side of a tributary outside a residential area. Second, for rivers in residential areas, border formed are estimated to be sufficient for inspection roads between 10-15 meters. While the criteria for the area around the water spring is at least in radius of 200 meters from the water spring.

\section{Table 3}

Protected Areas in the Study Area

\begin{tabular}{|c|c|c|}
\hline No. & Type of Protected Area & Area (Ha) \\
\hline 1. & Protected Forest & 84,40 \\
\hline 2. & Water Catchment Area & 374,44 \\
\hline 3. & Beach Border & 142,61 \\
\hline 4. & River Border & 675,07 \\
\hline 5. & Area around Water Springs & 25,12 \\
\hline 6. & Area of Nature and Cultural Reserves & 214,93 \\
\hline 7. & Areas Prone to Natural Disasters & 933,93 \\
\hline & Total Area (Ha) & $2.450,50$ \\
\hline
\end{tabular}

The nature reserve and cultural reserve area consist of nature reserves, wildlife reserves, forests for tourism, germplasm conservation areas, and animal refuge areas. Protection of nature reserves and cultural reserves is carried out to preserve the diversity of biota, ecosystem types, natural phenomena and uniqueness for the benefit of germplasm, science, and development in general. While protection of areas prone to natural disasters is to protect people and their activities from disasters caused by nature or indirectly by human actions. Criteria for 
areas prone to natural disasters are areas having high potential for natural disasters such as volcanic eruptions, earthquakes, and landslides. Table 3 and figure 1 show the entire protected area in the study area. Table 3 displays that the land of the protected area is $2.450,50 \mathrm{Ha}$ or $14,16 \%$ of the study area. Thus, the land of the cultivation area is $14.860,53 \mathrm{Ha}$ or $85,84 \%$ of the total land area.

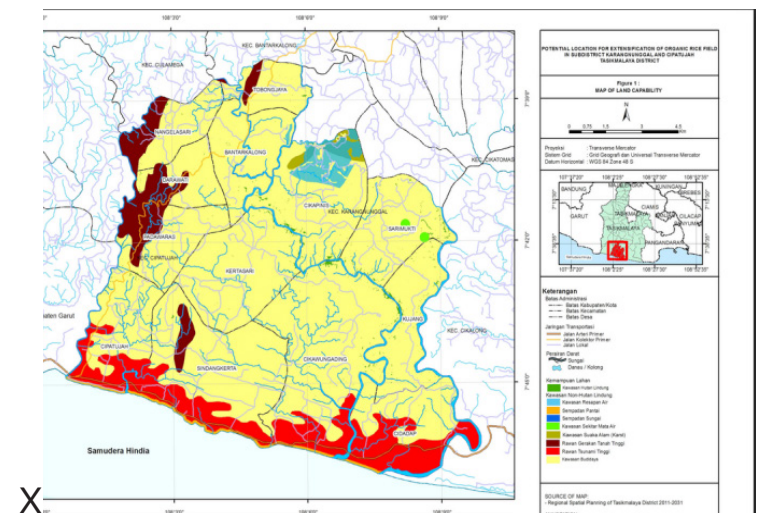

Figure 1 Tasikmalaya District

After determining protected and cultivation areas, the next step is to conduct land suitability analysis. Land suitability is a description of the suitability of a piece of land for certain uses, in this case, rice field. Land suitability analysis is only carried out in areas that have been declared as cultivation areas. Table 4 shows 9 land units that formed after overlaying.

Table 4

\section{Protected Areas in the Study Area}

Land Unit (LU) in Study Area
\begin{tabular}{|c|c|c|c|c|c|}
\hline LU & Slope & Altitude & Agroclimate & Flood & $\begin{array}{c}\text { Soil } \\
\text { Type }\end{array}$ \\
\hline 1 & $0-8$ & $<500$ & C2 & No Flood & Alluvial \\
\hline 2 & $8-40$ & $<500$ & C2 & No Flood & Alluvial \\
\hline 3 & $>40$ & $<500$ & C2 & No Flood & Alluvial \\
\hline 4 & $0-8$ & $<500$ & C2 & No Flood & Andosol \\
\hline 5 & $8-40$ & $<500$ & C2 & No Flood & Andosol \\
\hline 6 & $>40$ & $<500$ & C2 & No Flood & Andosol \\
\hline 7 & $0-8$ & $<500$ & C2 & No Flood & Podsolik \\
\hline 8 & $8-40$ & $<500$ & C2 & No Flood & Podsolik \\
\hline 9 & $>40$ & $<500$ & C2 & No Flood & Podsolik \\
\hline
\end{tabular}

The results of land suitability analysis can be seen in Table 5 and Figure 2. Based on Table 5, the area of land suitable for rice field is land suitability class $S_{2}$ (moderately suitable) and $\mathrm{S}_{3}$ (marginally suitable) totaling $10.155,01$ hectare or $58,66 \%$ of the study area.

The third step is to calculate the availability of irrigation water for the development of organic rice fields. The potential of water that can be fulfilled for irrigation water requirements comes from rain, rivers, and irrigation networks in the study area.

Table 5

Result of Land Suitability Analysis

\begin{tabular}{r|c|l|r}
\hline No. & $\begin{array}{c}\text { Land } \\
\text { Suitability }\end{array}$ & \multicolumn{1}{|c}{ Description } & Area (Ha) \\
\hline 1 & S2 & Moderately suitable & $4.684,87$ \\
\hline 2 & S3 & Marginally suitable & $5.470,14$ \\
\hline 3 & N1 & Currently not suitable & $4.705,52$ \\
\hline 4 & N2 & Permanently not suitable & $\mathbf{2 . 4 5 0 , 5 0}$ \\
\hline \multicolumn{3}{|c}{ Total } & $\mathbf{1 7 . 3 1 1 , 0 3}$ \\
\hline
\end{tabular}

The amount of effective rainfall for rice plants is $70 \%$ of the average amount of monthly rainfall. The amount of effective rainfall can be discovered based on data on the amount of monthly rainfall in the study area as seen in Table 6.

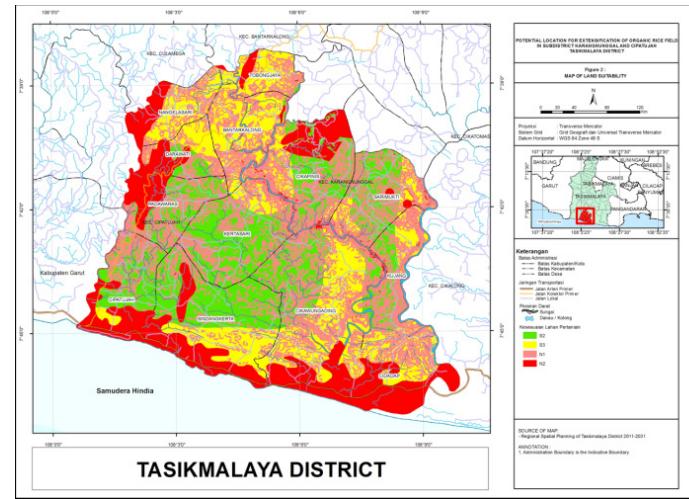

Figure 2

Table 6

The Amount of Effective Rainfall for Rice Plants

\begin{tabular}{|l|r|r|r|}
\hline Month & $\begin{array}{c}\text { The Amount } \\
\text { of Monthly } \\
\text { Rainfall } \\
\text { (mm/month) }\end{array}$ & $\begin{array}{c}\text { The Amount } \\
\text { of Daily } \\
\text { Rainfall } \\
\text { (mm/day) }\end{array}$ & $\begin{array}{c}\text { The Amount } \\
\text { of Effective } \\
\text { Rainfall } \\
\text { (mm/day) }\end{array}$ \\
\hline January & 303 & 10,1 & 7,07 \\
\hline February & 286 & 9,53 & 6,67 \\
\hline March & 243 & 8,1 & 5,67 \\
\hline April & 281 & 9,37 & 6,56 \\
\hline May & 197 & 6,57 & 4,60 \\
\hline June & 146 & 4,87 & 3,41 \\
\hline July & 120 & 4 & 2,80 \\
\hline August & 92 & 3,07 & 2,15 \\
\hline September & 143 & 4,77 & 3,34 \\
\hline October & 221 & 7,37 & 5,16 \\
\hline November & 320 & 10,67 & 7,47 \\
\hline December & 266 & 8,87 & 6,21 \\
\hline
\end{tabular}

The river in the study area is Cilangla River. Table 7 below reveals the potential discharge for irrigation water supply by assuming that the irrigation potential discharge 
is $20 \%$ and also based on data obtained from the Water Resources Management Office of Ciwulan-Cilaki River Region.

Table 7

Potential Discharge for Irrigation

\begin{tabular}{|c|c|c|c|c|}
\hline Month & $\begin{array}{c}\text { IWR } \\
(\mathrm{I} / \mathrm{sec})\end{array}$ & $\begin{array}{c}\text { Irrigation } \\
\text { Discharge } \\
(1 / \mathrm{sec})\end{array}$ & $\begin{array}{c}\text { River Discharge } \\
(1 / \mathbf{s e c})\end{array}$ & $\begin{array}{c}\text { Potential } \\
\text { Discharge for } \\
\text { Irrigation (1/sec) }\end{array}$ \\
\hline January & $-621,42$ & 1.805 & 53.436 .275 & $10.687 .255,00$ \\
\hline February & 194,45 & 1.600 & 64.602 .000 & $12.920 .400,00$ \\
\hline March & $-1.398,25$ & 1.639 & 26.610 .590 & $5.322 .117,90$ \\
\hline April & 944,97 & 1.494 & 14.948 .570 & $2.989 .714,00$ \\
\hline May & $1.414,62$ & 1.400 & 14.074 .500 & $2.814 .900,00$ \\
\hline June & $1.383,98$ & 1.418 & 4.265 .000 & $853.000,00$ \\
\hline July & $1.339,75$ & 1.419 & 3.847 .215 & $769.443,00$ \\
\hline August & 725,39 & 1.549 & 1.733 .500 & $346.700,00$ \\
\hline September & $1.228,14$ & 1.658 & 4.754 .675 & $950.935,00$ \\
\hline October & 315,56 & 1.870 & 1.814 .075 & $362.815,00$ \\
\hline November & $-1.437,30$ & 1.871 & 44.187 .042 & $8.837 .408,40$ \\
\hline December & $1.110,99$ & 1.818 & 53.436 .275 & $10.687 .255,00$ \\
\hline Total & $5.200,87$ & $19.539,00$ & $287.709 .716,50$ & $57.541 .943,30$ \\
\hline Average & 433,41 & $1.628,25$ & $23.975 .809,71$ & $4.795 .161,94$ \\
\hline
\end{tabular}

Based on table 7, the average potential of irrigation water from the Cilangla Riveris 4.795.161,94 liters/second. If the value of irrigation water requirement is $2,15 \mathrm{It} / \mathrm{sec} /$ ha, then the area of irrigable land will be 2.230.307,88 hectares which can fulfill water/ irrigation needs of all suitable land for rice fields.

Table 8

The Balance of Padawaras Irrigation

\begin{tabular}{|l|r|r|r|}
\hline \multicolumn{1}{|c|}{ Month } & \multicolumn{1}{c|}{$\begin{array}{c}\text { IWR } \\
(\mathbf{I} / \mathbf{s e c})\end{array}$} & $\begin{array}{c}\text { Irrigation } \\
\text { Discharge } \\
\text { (I/sec) }\end{array}$ & \multicolumn{1}{c|}{$\begin{array}{c}\text { Balance } \\
\text { (I/sec) }\end{array}$} \\
\hline January & $-621,42$ & 1.805 & 1.805 \\
\hline February & 194,45 & 1.600 & $1.405,55$ \\
\hline March & $-1.398,25$ & 1.639 & 1.639 \\
\hline April & 944,97 & 1.494 & 549,03 \\
\hline May & $1.414,62$ & 1.400 & $-14,62$ \\
\hline June & $1.383,98$ & 1.418 & 33,52 \\
\hline July & $1.339,75$ & 1.419 & 79,25 \\
\hline August & 725,39 & 1.549 & 823,11 \\
\hline September & $1.228,14$ & 1.658 & 429,36 \\
\hline October & 315,56 & 1.870 & $1.554,44$ \\
\hline November & $-1.437,30$ & 1.871 & 1.871 \\
\hline December & $1.110,99$ & 1.818 & 706,51 \\
\hline Total & $\mathbf{5 . 2 0 0 , 8 7}$ & $\mathbf{1 9 . 5 3 9 , 0 0}$ & $\mathbf{1 0 . 8 8 1 , 1 6}$ \\
\hline Average & $\mathbf{4 3 3 , 4 1}$ & $\mathbf{1 . 6 2 8 , 2 5}$ & $\mathbf{9 0 6 , 7 6}$ \\
\hline \multicolumn{4}{|l}{ Source: Processing results }
\end{tabular}

Padawaras irrigation canal is the only technical irrigation canal in the study area. Padawaras irrigation canal has a service area of 1.530 ha. The source of Padawaras irrigation water comes from Cilangla River which has an average half-monthly discharge of 23.975.809,71 It/sec. Based on the calculation result, the average irrigation water requirement in the study area are 0,84 $\mathrm{mm} /$ day or $433,41 \mathrm{lt} / \mathrm{sec}$. The average water discharge of Padawaras irrigation reaches $1.628,25 \mathrm{lt} / \mathrm{sec}$ every month. The comparison between irrigation water requirements and water availability of Padawaras irrigation produces a balance or difference that can indicate the excess or lack of water that occurs in the study area. Table 8 shows further details.

Based on the calculation of water balance, the average irrigation water requirement has a value of $906,76 \mathrm{It} / \mathrm{sec}$, showing that the available irrigation water discharge can fulfill the irrigation water requirements. In January, March, and November, irrigation water requirements have negative values which indicate that the water supply obtained from rainfall is sufficient so that it does not need irrigation from the irrigation network. The shortage of water supply in May with a value of $-14,62$ It/sec shows that agricultural land requires an additional irrigation water discharge of $14,62 \mathrm{lt} / \mathrm{sec}$.

The location of organic rice extensification is determined by overlaying the results of the analysis that has been done. As mentioned earlier, the location of organic rice extensification should comply the following criteria: (1) it is not a protected area; (2) minimal land suitability is according to marginal $\left(\mathrm{S}_{3}\right)$; and $(3)$ there is a source of water for irrigation. The result of land suitability analysis shows that potential land for the new rice field is $10.155,01$ hectares, while the result of irrigation water availability analysis reveals that the water needs of all potential land mention above can be fulfilled. Based on figure 2 of land suitability map, the potential land area of each village that can be developed into rice fields is shown in Table 9.

Table 9

Potential Land in Beach Village

\begin{tabular}{|c|c|c|c|}
\hline No & Subdistrict & Village & Area (Ha) \\
\hline 1 & \multirow{4}{*}{ Karangnunggal } & Cidadap & $1.022,85$ \\
\hline 2 & & Cikapinis & 845,89 \\
\hline 3 & & Kujang & 420,06 \\
\hline 4 & & Sarimukti & 503,20 \\
\hline 5 & \multirow{9}{*}{ Cipatujah } & Bantarkalong & 541,53 \\
\hline 6 & & Cikawunggading & $1.634,08$ \\
\hline 7 & & Cipatujah & $1.116,90$ \\
\hline 8 & & Darawati & 364,97 \\
\hline 9 & & Kertasari & 908,94 \\
\hline 10 & & Padawaras & 437,96 \\
\hline 11 & & Sindangkerta & $1.648,57$ \\
\hline 12 & & Tobongjaya & 336,93 \\
\hline 13 & & Nangelasari & 373,13 \\
\hline \multicolumn{3}{|c|}{ Total } & $10.155,01$ \\
\hline
\end{tabular}

The average production of rice fields 
in Tasikmalaya District is 7,76 tons/ha. If all suitable land is planted with rice twice a year, the potential of annual organic rice production can reach $157.605,76$ tons.

\section{Conclusions}

The protected areas consist of protected forest areas, water catchment areas, coastal borders, river borders, water springs areas, nature reserves and cultural reserves, and areas prone to natural disasters. Cultivation area dominates almost all the study area (more than three quarter of it), and the rest is protected area. Meanwhile, suitable areas developed for rice fields cover more than a half of the study area. The availability of water in the study area is sufficient to meet all the water needs for the rice fields to be developed. The potential rice production is more than 100 tons/year.

Rice fields equipped with irrigation networks will become a physical foundation for the development of organic rice fields in the future. Therefore, the construction of irrigation networks on potential land for organic rice fields should be a priority. The provision of this irrigation network will guarantee the availability of water for planting rice twice a year and can avoid crop failures caused by the lack of water.

\section{References:}

Amalia, E. (2013). Perbedaan Sistem Tata Niaga Beras Organik dengan Beras Anorganik. Sumatera Utara: Program Studi Agribisnis Universitas Sumatera Utara.

Andoko, A. (2005). Budidaya Padi Secara Organik. Jakarta: Penebar Swadaya.

AOI (Indonesian Organic Alliance). (2018). 13 Ton Beras Organik Asal Tasikmalaya Dikirim ke Italia. dalam Website: http:// aoi.ngo/web/13-ton-beras-organik-asaltasikmalaya-dikirim-ke-italia/. Accessed on October 11, 2019.

Chofyan, I. (2016). The Dynamics of Rice Field Conversion into Settlement in the District of Bandung. Mimbar; Social and Development Journal.Vol 32, No. 2, Desember 2016. Bandung: P2U-LPPM Unisba. Page 267-275.

Darwanto, D. H. (1999). Peranan Irigasi Pertanian dalam Meningkatkan Produksi dan Pendapatan Petani. Jurnal Agro Ekonomi Vol. 6, No. 1, 1999. Page 45-71.
Fagi, A.M., \& Las, I. (2007). Membekali Petani dengan Teknologi Maju Berbasis Kearifan Lokal pada Era Revolusi Hijau Lestari. in Karsyno, F. Membalik Arus Menuai Kemandirian Petani. Jakarta: YayasanPadi Indonesia.

Firmanto, B.H. (2011). Sukses Bertanam Padi Secara Organik. Bandung: Angkasa.

Greer, G. (2008). Comparison of the Financial Performance of Organic and Conventional Farms. New Zealand: Lincoln University.

Gribaldi. (2009). Pertanian Organik dan Teknologi Pendukungnya. AgronobiS, Vol. 1, No. 2, September 2009. Page 19-24.

Hamka, E., Amir M., Sitti R. M., Rita L. B., \& Ary T. (2018). Sistem Organik untuk Pengembangan Pertanian Organik di Desa Lamomea Kabupaten Konawe Selatan. Jurnal Dedikasi, ISSN 1693-3214. Volume 15, Mei 2018. Page 62-70.

IFOAM. (2005). Prinsip-Prinsip Pertanain Organik. Adelaide: IFOAM General Assembly.

Imani, F., Anne Ch., Tuti K., \& Gema W. M. (2018). Application of Organic Farming System in Mekar Tani Jayafarmer Group Cibodas Village Bandung Barat Regency. Mimbar Agribisnis; Jurnal Pemikiran Masyarakat Ilmiah Berwawasan Agribisnis. 4(2), 2018. Page 139-152

Kementerian Pertanian. (2007). Road Map Pengembangan Pertanian Organik 20082015. Jakarta.

Keputusan Presiden Republik Indonesia Nomor 32 Tahun 1990 tentang Pengelolaan Kawasan Lindung.

Khorniawati, M. (2014). Produk Pertanian Organik di Indonesia: Tinjauan atas Preferensi Konsumen Indonesia terhadap Produk Pertanian Organik Lokal. Jurnal Studi Manajemen, Vol. 8 No. 2, Oktober 2014. Page 171-182.

Lutfi, M. A. (2017). Analisis Pendapatan Usahatani Padi Organik dan Non Organik di Kabupaten Tasikmalaya Provinsi Jawa Barat. Bogor: InstiturPertanian Bogor.

Muchtadi, T. (2010). Ilmu Pengetahuan Bahan Pangan. Bogor: Alfabeta.

Partowijoto, A. (1996). Kapita Selekta Teknik Tanah dan Air. Bogor: Institut Pertanian Bogor.

Peraturan Daerah Kabupaten Tasikmalaya Nomor 2 Tahun 2012 tentang Rencana Tata Ruang Wilayah (RTRW) Kabupaten Tasikmalaya Tahun 2011-2031.

Perda Kabupaten Tasikmalaya Nomor 5 Tahun 2016 tentang Rencana Pembangunan Jangka Menengah Daerah (RPJMD) Kabupaten Tasikmalaya Tahun 2016- 
2021.

Perda Kabupaten Tasikmalaya Nomor 4 Tahun 2016 tentang Perlindungan Lahan Pertanian Pangan Berkelanjutan.

Permatasari, P., Sapja A., Widyatmani S. D. (2018). Pengaruh Tingkat Adopsi Budidaya Padi Organik terhadap Keberlanjutan Budidaya Padi Organik di Kabupaten Boyolali. Caraka Tani: Journal of Sustainable Agriculture. 33(2), 2018, Page 153-168.

PP Nomor 13 Tahun 2017 tentang Rencana Tata Ruang Wilayah Nasional (RTRWN).

Rusiyah, M. R., Djarot S. W., \&Tukidal Y. (2012). Studi Pengembangan Pertanian Padi Sawah Organik Berdasarkan Kesesuaian Lahan dan Potensi Pupuk Organik dari Limbah Pertanian di Kecamatan Temon Kabupaten Kulon Progo. MGI Vol. 26, No. 2, September 2012, Page 190-203.

Saragih, S.E. (2008). Pertanian Organik: Solusi Hidup Harmoni dan Berkelanjutan.
Jakarta: Penebar Swadaya.

Sarief, S. (1996). IImu Tanah Pertanian. Bandung: Pustaka Buana.

Sriyanto, S. (2010). Panen Duit dari Bisnis Padi Organik. Jakarta: Agro Media.

Supartha, I. N. Y., Wijana, G., \& Menaka, G. A. (2012). Application Types of Organic Fertilizer for Rice (Oryza sativa L.) in Organic Farming Systems. E-Jurnal Agroekoteknologi Tropika, ISSN: 23016515, Vol. 1, No. 2, Oktober 2012, Page 98-106.

Sutanto, R. (2002). Pertanian Organik: Menuju Pertanian Alternatif dan Berkelanjutan. Yogyakarta: Kanisius.

Wiratmadja, I. I., Noneng N., \& Amelia K. (2017). Model Penerimaan Petani terhadap Teknologi Sistem Pertanian Organik di Kabupaten Tasikmalaya. Jurnal Manajemen Teknologi, 16(1), 2017, Page 81-91. 